\title{
STUDY OF SEASONAL VARIATION IN PHYSICO-CHEMICAL PARAMETERS OF WATER IN MANIKA MON OF MUZAFFARPUR, BIHAR, INDIA RAGINI KUMARI ${ }^{\mathrm{a} 1}$ AND POONAM SINHA ${ }^{\mathrm{b}}$
}

${ }^{a}$ Research Scholar, Department of Botany, B.R.A. Bihar University, Muzaffarpur, Bihar, India

${ }^{b}$ Department of Botany, M.D.D.M. College, B.R.A. Bihar University, Muzaffarpur, Bihar, India

\begin{abstract}
Changes in modern life style and use of heavy amounts of agrochemicals and fertilizers have caused a scenario due to which there are undesired changes in physico-chemical parameters of water, soil and air. Anthropogenic activities thus have enhanced the quantum of pollution of fresh water ponds and Mons. Water quality has tremendous impact on flora and fauna. Manika Mon is a perennial water reservoir of Muzaffarpur. Because water of this Mon is being used for different purposes, so its physico-chemical analysis was done in different seasons. Temperature of surface water was taken from February to March, May to July, August to September and November to January. Similar studies were also conducted for different parameters. The mean of the data for $\mathrm{pH}$ varied from 7.10 May to July, to 8.30 from February to March. In the same periods temperature varied from $13.6^{\circ} \mathrm{C}$ to $29.5^{\circ} \mathrm{C}$. Turbidity varied between $48.0 \mathrm{~cm}$ to $116 \mathrm{~cm}$, soluble substances from $1022 \mathrm{mg}$ to $1150 \mathrm{mg} / \mathrm{l}$, while dissolved oxygen varied between $5.62 \mathrm{mg} / \mathrm{l}$ to $10.16 \mathrm{mg} / \mathrm{l}$, free carbon dioxide $12.58 \mathrm{mg} / \mathrm{l}$ to $16.72 \mathrm{mg} / \mathrm{l}$, chloride $28.75 \mathrm{mg} / \mathrm{l}$ to $47.70 \mathrm{mg} / \mathrm{l}$, calcium $6.18 \mathrm{mg} / \mathrm{l}$ to $12.19 \mathrm{mg} / \mathrm{l}$ and Ca-hardness $8.26 \mathrm{mg} / \mathrm{l}$ to $19.71 \mathrm{mg} / \mathrm{l}$. Therefore, it is essential that the water body should be put under strict vigilance and constant monitoring so that the water should be maintained at its better quality.
\end{abstract}

KEYWORDS: Physico-chemical characteristic, Anthropogenic, Agrochemical, Dissolve Oxygen, Free Carbon dioxide, Cahardness

Purity of water depends on the concentrations of different component. The surrounding of the water bodies, particularly the ponds and Mon, also influences the physico-chemical properties. This is also true for the human activities. Pond water is generally utilized by the populations, which are present near the water body. Whether the components are as per the quantity, which are recommended for its utilization or they are present in excess can be monitored by analyzing these parameters. We get several literatures where physico-chemical analysis of water has been done. Some of them may be cited here such as, Dwivedi and Pandya (2002); Srivastva et al., (2003); Murthi and Yajurvedi (2004); Narayana et al., (2005); Singh \& Mathur (2005); Gupta and Shukla (2006); Shah et al., (2006); Chaurasia and Pandey (2007); Araoye (2009); Bhat et al., (2010); Chandra et al., (2010); Ehiagbonare et al., (2010); Mahananda et al., (2010); Arya et al., (2011); Baswaraja et al., (2011); Sinde et al., (2011); Medudhula et al., (2012); Jena et al., (2013); Nag and Gupta (2014); Uduma and Uduma (2014); Verma \& Khan (2015); Bhayali et al., (2016); Balkrishnan et al., (2017); Saha et al., (2017) and Ramnathan and Asmsath (2018).

The purpose of the present study was to analyze the water quality for Manika Mon, which is a perennial water reservoir for the local people. Physico-chemical analysis in different seasons gave different data for different parameters generally considered for the water analysis. So a correlation between the parameters and the season may be established.

\section{MATERIALS AND METHODS}

Study Site

Manika Mon is $8 \mathrm{~km}$ away from the main town of Muzaffarpur. The study was conducted for a period of one year from August 2016 to July 2017. Once the water of Manika Mon was free from different pollutant and the different components were under the prescribed concentration. But due to anthropogenic activities the quality of water has degraded. Variety of weeds may be seen growing on the marginal land of the Mon.

\section{Sample Collection}

Water samples of Manika Mon were collected in pre-sterilized containers and beaker in different seasons at 9.3 to $10.30 \mathrm{AM}$ at a depth of $20-30 \mathrm{~cm}$ from the surface. The closed bottles were dipped into the water and then the caps were removed. When the bottles were filled up completely and there was no air bubbles the caps were replaced on the bottles tightly. The parameters like $\mathrm{pH}$, temperature, turbidity etc. were studied at the site. For the 
evaluation of dissolved oxygen samples were collected separately in specific bottle and dissolved oxygen was fixed at the spot by adding $20 \mathrm{ml}$ each of Manganous sulphate $\left(\mathrm{MnSO}_{4}\right)$ and Alkali Azide Iodine. Precaution was taken during sample water collection so that there was no air bubbles at all. In the Laboratory dissolved oxygen was analyzed following Winkler's titrimetric method.

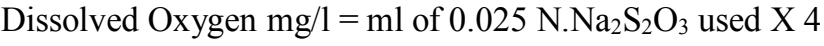

Free carbon dioxide was estimated by Standard titrimetric method using phenolphthaline as indicator. Calculation was made as per the standard formula provided by different text books.

Transparency was determined during sunny day and there were no clouds or wind current. The sinking Secchi disc was observed directly above, while the sun was behind. The points at which the disc disappeared and it reappeared were noted and calculation was made by applying the formula provided.

Total soluble substances were calculated by evaporating the known volume of sample water in dried and pre-weighed porcelain cup. From the final weight the weight of the cup was deducted that gave the particles present in the known volume.

Temperature was also taken at the spot with the help of a mercury thermometer.

\section{Chloride}

Chloride was also determined by titrimetric method, where potassium dichromate was used as indicator and titration was done with $0.07 \mathrm{~N} \mathrm{AgNo}_{3}$.

Chloride $(\mathrm{ppm})=(\mathrm{ml} \times \mathrm{N})$ of $\mathrm{AgNo}_{3} \times 1000 \times 35.5 / \mathrm{ml}$ of sample.

\section{Calcium}

It was estimated by EDTA, titrimetric method.

Calcium $(\mathrm{ppm})=\mathrm{X} \times 400.8 / \mathrm{ml}$ of sample

$$
\text { Where } \mathrm{X}=\text { Volume of EDTA used. }
$$

\section{Ca-hardness}

This value was determined by total amount of calcium in known volume of sample multiplied by a factor of 2.497 .
All experiments were done in triplicate and the mean was used as data for discussion and conclusion.

\section{RESULTS AND DISCUSSION}

Manika Mon was selected for its physico-chemical studies. From the Graph 1, It was noted that temperature of the surface water was observed in different season. The minimum temperature was recorded from November to January where the mean temperature was $13.16^{\circ} \mathrm{C}$. In February to March it was $16.7^{\circ} \mathrm{C}$, while the maximum mean temperature was noted form May to July which was $29.5^{\circ} \mathrm{C}$. These mean temperature again fell down to $22.3^{\circ} \mathrm{C}$ from August to September.

From the Graph 1, it was noted that, $\mathrm{pH}$ value of the above Mon varied from 7.10 to 8.30 . Maximum $\mathrm{pH}$ was recorded from February to March, followed by November to January 8.15 , while minimum $\mathrm{pH}$ was from May to July 7.10. This variation may be due to productivity of the Mon.

From the Graph 1, it was noted that, turbidity indicated the amount of materials suspended in water bodies. In the present study maximum transparency was noted form November to January $(116 \mathrm{~cm})$, followed by February to March $(112 \mathrm{~cm})$. Here minimum transparency $48.0 \mathrm{~cm}$ was noted May to July. From August to October it was $105 \mathrm{~cm}$ only.

\section{Total Soluble Substances}

In the present study from the Graph 2, it was noted that maximum solid was $11580 \mathrm{mg} / \mathrm{l}$ from May to July, followed by $1088 \mathrm{mg} / \mathrm{l}$ from November to January. Here minimum $1022 \mathrm{mg} / \mathrm{l}$ was noted from February to April.

\section{Dissolved Oxygen}

From the Graph 1, it was noted that, dissolved Oxygen of the water sample of the Mon was also calculated. Maximum value $10.16 \mathrm{mg} / \mathrm{l}$ was found from November to January, which was followed by $9.4 \mathrm{mg} / 1$ from February to March and $8.56 \mathrm{mg} / \mathrm{l}$ from August to October. Minimum amount of oxygen was noted 5.62 from May to July. So amount of Oxygen varied from 5.62 to $10.16 \mathrm{mg} / \mathrm{l}$ of pond water.

\section{Free Carbon Dioxide}

In the present study from the Graph 1, it was indicated that, free carbon dioxide varied form $12.58 \mathrm{mg} / \mathrm{l}$ 
to $16.72 \mathrm{mg} / \mathrm{l}$. Here maximum amount of free carbon dioxide was noted form February to March that was 16.72 $\mathrm{mg} / \mathrm{l}$. This was followed by $15.18 \mathrm{mg} / \mathrm{l}$ from May to July. Here $14.34 \mathrm{mg} / \mathrm{l}$ was noted form, August to October, while the amount of free $\mathrm{Co}_{2}$ from November to January was only $12.58 \mathrm{mg} / \mathrm{l}$ of the sample water.

\section{Chloride}

From the Graph 1, it was noted that, the amount of chloride in the sample water was also calculated. Here maximum $47.70 \mathrm{mg} / \mathrm{l}$ was calculated from November to January followed by $44.68 \mathrm{mg} / \mathrm{l}$ from February to April. This was followed by $42.34 \mathrm{mg} / \mathrm{l}$ from May to July. Lowest amount $28.75 \mathrm{mg} / 1$ was observed from August to October. So it varied from $28.75 \mathrm{mg} / 1$ to $47.70 \mathrm{mg} / 1$ of the sample water.

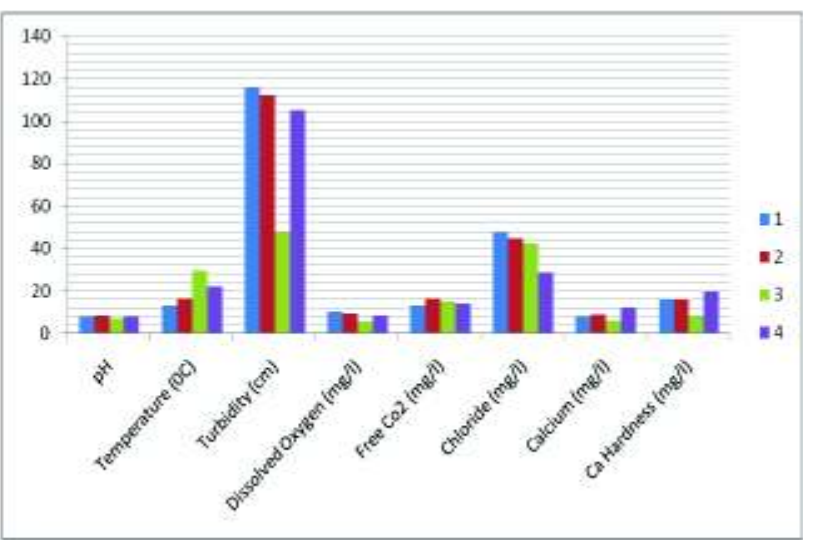

Graph 1: Showing seasonal variations in different parameters used for physico-chemical analysis of water of Manika Mon.

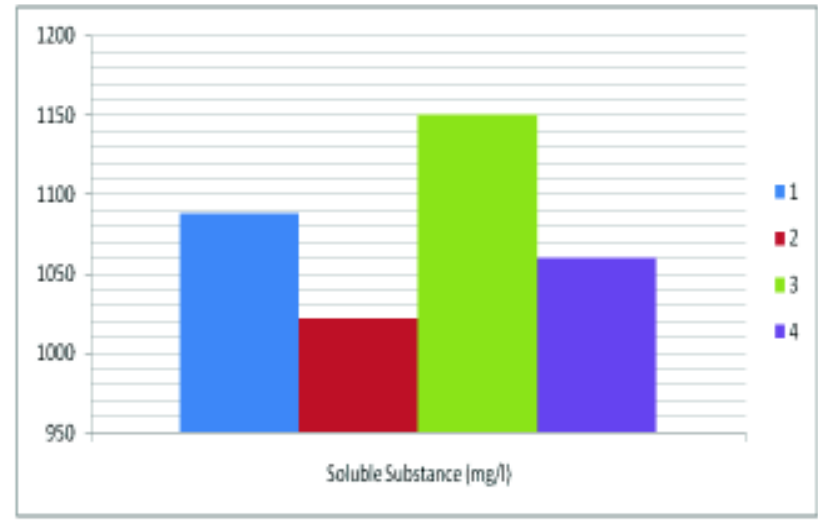

Graph 2: Showing seasonal variations in Total Soluble Substances used for physico-chemical analysis of water of Manika Mon.
Note (For Graph 1\&2): 1= November to January, $2=$ February to April, 3 = May to July, 4= August to October

\section{Calcium}

Calcium present in the sample water was also calculated. It was observed from the Graph 1, that, here maximum $12.19 \mathrm{mg} / 1$ was noted form August to October, followed by $8.74 \mathrm{mg} / \mathrm{l}$ from February to April. $8.09 \mathrm{mg} / \mathrm{l}$ of calcium was noted from November to January and lowest concentration of calcium $6.18 \mathrm{mg} / \mathrm{l}$ from May to July. Thus amount of calcium varied from $12.19 \mathrm{mg} / \mathrm{l}$ to $6.18 \mathrm{mg} / \mathrm{l}$ in different seasons.

\section{Ca-hardness}

Here it was noted from the Graph 1, that the mean value of calcium hardness was the highest $19.71 \mathrm{mg} / 1$ from August to October, followed by $16.08 \mathrm{mg} / \mathrm{l}$ from February to March and $16.07 \mathrm{mg} / 1$ from November to January.

It was the minimum 8.26 from May to July. Therefore, Calcium hardness varied from 19.71 to 8.26 $\mathrm{mg} / \mathrm{l}$ in the different seasons.

\section{DISCUSSION}

Different parameters of physico-chemical analysis of water evaluated in the present work revealed seasonal variations. $\mathrm{pH}$ value that is hydrogen ion concentration of water evaluated here revealed that water of Manika Mon was always alkaline as the $\mathrm{pH}$ values ranged between 7.10 to 8.30 .

So during February to April the water was maximum alkaline. Sharma et al., (1984) reported that in India, many small confined water pockets are particularly alkaline in nature. Here it was noted that $\mathrm{pH}$ was highest 8.30 in February to April. Above findings are in agreement with the findings of Saha et al., (2017) who also reported that an average $\mathrm{pH}$ during summer was 7.15 and 8.3 during post monsoon.

\section{Temperature}

The mean of three months, of different season for temperature varied from 13.16 to $29.5^{\circ} \mathrm{C}$. It is reported that temperature of small water reservoir fluctuates according to the seasons and in depth of water. Here also during summer the surface temperature was highest because temperature of 


\section{KUMARI AND SINHA: STUDY OF SEASONAL VARIATION IN PHYSICO-CHEMICAL PARAMETERS OF...}

the air is highest during this. Above findings are in conformity with the findings of Barman et al., (2015) who also reported that temperature of pond water during summer ranged between 27.1 to 28.33 , while during winter it was $8.70^{\circ} \mathrm{C}$ to $12.7^{\circ} \mathrm{C}$.

\section{Turbidity}

This indicates the impurities suspended in water. It measures the amount of light scattered or absorbed, silt, clay, organic matter and plankton percentage determines the turbidity. Here turbidity during May to July was $48.0 \mathrm{~cm}$ only. This may be due to higher percentage of phytoplanktons and concentration of water of the pond. The maximum $116 \mathrm{~cm}$ during November to January may be due to dilution after monsoon and loss of phytoplankton. Above findings is also supported by the findings of Barman et al., (2015) and Sangeeta et al., (2017). Thus turbidity is caused by the suspended and colloidal matter, such as clay, silt, fine organic and inorganic matter and plankton. Due to this in present study also, fluctuation in turbidity was found in different seasons.

Soluble substances are not visible but when water is evaporated, the amount of residue indicates the soluble molecules present in a water sample. In the present work total dissolved solids value of water ranged from 1022.0 $\mathrm{mg} / \mathrm{l}$ to $1150 \mathrm{mg} / \mathrm{l}$. The highest amount was noted from the month of May to July, while the lowest during the February to April. Higher amount of soluble substances in water during summer may be due to higher concentration as the water is evaporated during this season and there is no dilution of present water.

Higher concentration of total dissolved solute/ nutrient may lead to eutrophication of the water body. This has been confirmed by Sahni and Yadav (2012); Verma and Khan (2015); Sharma and Ramendra (2016); Tamizhagan and Pugazhendy (2016).

Dissolved oxygen was also estimated in the present study for the water of Manika Mon. The amount of dissolved oxygen varied from 5.62 to 10.16 , while the highest amount was noted during November to January, $10.16 \mathrm{mg} / 1$ followed by $9.48 \mathrm{mg} / 1$ during February to April. The minimum $5.26 \mathrm{mg} / 1$ was found during summer. We know that at higher temperature oxygen is less dissolved in water. Due to this oxygen released by the phytoplankton \& other aquatic plants during day time due to photosynthesis is not dissolved in water, while at night maximum $\mathrm{O}_{2}$ are utilized by the phytoplanktons as well as by the aquatic plants. Present finding corroborates with the findings of Barman et al., (2015); Dixit et al., (2015); Sharma and Singh (2016); Balkrishnan et al., (2017) and Ramnathan and Amsath (2018).

\section{Chloride}

In the present study amount of chloride found in the Manika Mon water in different seasons was also studied. Here it was noted that its concentration varied from 28.75 to $47.70 \mathrm{mg} / \mathrm{l}$. Maximum concentration was from November to January, followed by February to March. Its concentration was minimum 28.75. From the month of August to September. Sharma and Singh (2016) also reported similar variations in the concentration of chloride. Higher concentration indicates polluted condition of the water that may influence the growth of vegetation.

\section{Calcium}

Amount of Calcium was also calculated in different seasons. This varied from $12.19 \mathrm{mg} / 1$ to $6.18 \mathrm{mg} / \mathrm{l}$. Higher concentration was observed from August to October while the minimum from May to July. Barman et al., (2015) also observed the similar result. So present finding is in agreement with the above workers. Concentration of calcium, aids to the hardness of water, calcium hardness was also studied. Here $19.71 \mathrm{mg} / \mathrm{l}$ was the maximum found during August to October and Minimum 8.28 found during May to June. Source of Calcium in fresh water pond is the agro-chemicals containing Calcium, which are carried by the rain water from the field to the water bodies.

\section{CONCLUSION}

Physico-chemical studies were done in different seasons. The findings clearly indicate that there are variations in different parameters considered here. Because surrounding people are utilizing this water so its annual monitoring is essential.

\section{ACKNOWLEDGEMENT}

Authors are thankful to the Head, University Department of Botany, B.R.A. Bihar University, Muzaffarpur for providing Laboratory facilities. 


\section{KUMARI AND SINHA: STUDY OF SEASONAL VARIATION IN PHYSICO-CHEMICAL PARAMETERS OF...}

\section{REFERENCES}

Araoye P.A., 2009. The seasonal variations of $\mathrm{pH}$ and dissolve oxygen $\left(\mathrm{DO}_{2}\right)$ concentration in Asa Lake, Nigeria. Int. J. of Physical Sciences, 4(5): 271-274.

Arya S., Kumar V., Raikwar M., Dhaka A. and Minakshi, 2011. Physico-chemical analysis of selected surface water samples of Laxmi Tal (pond) in Jhansi, U.P., Indian J. of Experimental Sciences, 2(8): 01-06.

Balakrishnan S., Chelladurai G., Mohan Raj J. and Poongodi J., 2017. Seasonal variations in physicochemical characteristics of Tutyicorin coastal waters, South East Coast, India. Applied Water Science, 7(4): 1881-1886.

Barman D., Roy B. and Roy S., 2015. Seasonal variations of physico-chemical characteristics of wet lands in the West Garo Hill, Meghalaya, India. Int. Res. J. of Biological Sci., 4(1): 60-65.

Baswaraja, Simpi S.M., Hiremath K.N.S., Murthy K.N., Chandra Shekhrappa A.N. and Patel E.T.P., 2011. Analysis of water quality, using physico-chemical parameters, Hassaballi Tank in Karnataka, India. Indian Global J. of Sci. Frontier Res., 1(3): 31-34.

Bhat M.M., Narain K., Ahmad A., Shukla R.N. and Yunus M., 2010. Seasonal variations of physico-chemical characteristics in several ponds of Lucknow city affected by urban drainage. Advance Environmental Biology, 6(10): 2654-2663.

Bhayali A., Kanhere R.R. and Pandit H., 2016. Physicochemical analysis of Sajvay pond in fresh water area of Barwani District., M.P., India. Int. J. of Curr. Innov. Res., 2(12): 529-531.

Chandra S., Singh A., Tomar P.K. and Kumar A., 2010. Evaluation of physico-chemical characteristics of various river water in India. Journal of Chemistry, 8(4): 1546-1555.

Chaurasia M. and Pandey G.C., 2007. Study of physicochemical characteristics of some water ponds of Ayodhya, Faizabad. Indian J. Environ. Protection, 27(11): 1019-1023.

Dixit A.K., Pandey S.K., Mehta R., Ahmad N., Gunjan and Pandey J., 2015. Study of physico-chemical parameters of different pond water of Bilashpur District, Chhattisgarh, India. Environmental Skeptics \& Critics, 4(3): 89-95.

Dwivedi B.K. and Pandey G.C., 2002. Physico-chemical factors and algal diversity of two ponds (Girija and Maqubara Pond), Faizabad. Pollution Research, 21: 361-370.

Ehiagbonare J.E. and Ogundiran Y.O., 2010. Physicochemical analysis of Fish-pond water in Okada and its environment. African J. Biotech, 9(36): 5922-5928.

Gupta S. and Shukla D.N., 2006. Physico-chemical analysis of sewage water and its impact on seed germination and seedling growth of Sesamum indicum. J. of Research in National Development, 1: 15-19.

Jena V.S. Dixit, Srivastva R. and Gupta S., 2013. Study of pond water quality by assessment of physicochemical parameters and water quality index. Int. Journ. of Appl. Biol. and Pharmac. Technol., 4(1): 47-52.

Mahananda M.R., Mohanty B.P. and Behera M.N.R., 2010. Physico-chemical analysis of surface and ground water of Bargarh, District, Orissa. I.J.R.R.A.S., 2(3): 128-132.

Medudhula T., Ch. Samantha and Chintha S., 2012. Analysis of water quality using physico-chemical parameters in lower manir reservoir of Karim Nagar District. A.P., India. Int. J. Env. Sci., 3(1): 172-177.

Nag A. and Gupta H., 2014. Physico-chemical analysis of some water ponds in and around Shantiniketan, West Bengal, India. Int. J. of Env. Sciences, 4(5): 676-682.

Narayana J.R., Purushothama B.R., Kiran K.P., Kumar R. and Puttah E.T., 2005. Investigation of drinking water quality of Basavanahole tank with reference to physico-chemical characteristics. Fundamental of Limnology, 5: 201-206.

Parab S. and Pradhan N., 2015. Monitoring of seasonal variation in physico-chemical water parameters in 


\section{KUMARI AND SINHA: STUDY OF SEASONAL VARIATION IN PHYSICO-CHEMICAL PARAMETERS OF...}

Nalasopara Region. Journal of Ecosystem and Ecography, 13: 1-6.

Ramnathan S. and Asmsath A., 2018. Seasonal variations in physico-chemical parameters of Puthukulam Pond, Puddu Kottai, Tamil Nadu. Res. J. of Life. Science. Bioinformatics, Pharma \& Chem. Sci., 10: $181-187$.

Sachidananda Murthy K.L. and Yajurvedi H.N., 2004. Monthly variations in water quality parameters (physico-chemical) of a perennial lake in Mysore. Indian Hydrobiol. 7: 217-228.

Saha S., Mandal A.J. and Sahoo D.M., 2017. Study of physico-chemical parameters of three different urban pond water of Nadia District, West Bengal, India. Int. J. of Fisheries and Aquatic Studies, 5(6): 23-27.

Sahni K. and Yadav S., 2012. Seasonal variations in physicochemical parameters of Bharawas PondHaryana. Asian J. Exp. Sci., 26(1): 61-64.

Shah M.C., Shilpkar P.G., Prasar A. and Patiyal R.S., 2006. Seasonal variations in physico-chemical characteristics of Ranjit Sagar reservoir, J \& K. J. Ecophysiol. Occupat. Health, 6: 1-5.

Sharma M.S., Sharma L.L. and Durve V.S., 1984. Eutrophication of Lake Pichhola in Udaipur, Rajasthan. Poll. Res., 3(2): 39-44.

Sharma T.K. and Singh R., 2016. Seasonal variations in physico-chemical parameters of Laxmi Taal,
Jhansi, India. Int. J. Curr. MIcrobiol.. Appl. Sci., 5(12): 308-315.

Sinde S.E., Pathan T.S., Raut K.S. and Sonawane D.L., 2011. Studies on physico-chemical parameters and correlation coefficient of Harsool-Savangi Dame, Distt.- Aurangabad, India. Middle East Journ. of Scientific Research, 8(3): 544-544.

Singh S. and Mathur P., 2005. Investigation of variation of physico-chemical characteristics of a fresh water reservoir of Ajmer City, Rajasthan. Indian J. of Environ. Sci., 9: 57-61.

Srivastva N., Agarwal M. and Tyagi A., 2003. A study of physico-chemical characteristics of water bodies around Jaipur. J. of Environmental Biology, 24: $177-180$

Tamizhazhagan V. and Pugazhendy K., 2016. Physicochemical parameters from Manappa daiyur and Swami Malai fresh water ponds. Indian Am. J. Pharm. Sci., 3(5): 444-449.

Uduma A.U. and Uduma M.B., 2014. Physico-chemical analysis of the quality of Sachet water consumed in Kano Metropolis. American J. of Env. Energy and Power Res., 2(1): 01-10.

Verma S. and Khan J.B., 2015. Analysis of water quality by physico-chemical parameters in Fateh Sagar Talab in Bagar, Distt.- Jhunjhunu (Raj.) India, 10(5): 4145. 